Piotr Kusztal *, Ilona Żeber-Dzikowska **, Jarosław Chmielewski ***, Bożena Wójtowicz ****, Elżbieta Wszelaczyńska *****, Barbara Gworek ***

\title{
The significance of the European beaver (Castor fibre) activity for the process of renaturalization of river valleys in the era of increasing
}

Znaczenie działalności bobra europejskiego (Castor fiber) $\mathrm{w}$ procesie renaturalizacji dolin rzecznych $\mathrm{w}$ dobie narastającej antropopresji

\begin{abstract}
* Mgr Piotr Kusztal - Institute of Geography, the Jan Kochanowski University in Kielce, Świętokrzyska 15 St., 25-406 Kielce; email: roch1990@gmail.com ** Dr hab. llona Żeber-Dzikowska, prof. nadzw. - Institute of Humanities and Social Sciences, The State School of Higher Professional Education in Płock, Gałczyńskiego 28 St., 09-400 Płock; Institute of Biology, the Jan Kochanowski University in Kielce, Świętokrzyska 15 St., 25-406 Kielce

*** Dr Jarosław Chmielewski, prof. dr hab. Barbara Gworek - Institute of Environmental Protection-National Research Institute, Krucza 5/11d St., 00-548 Warsaw
\end{abstract}

Keywords: European beaver, renaturalization, land restoration, environment shaping, river valleys, anthropopressure Słowa kluczowe: bóbr europejski, renaturalizacja, renaturyzacja, kształtowanie środowiska, doliny rzeczne, antropopresja

\section{Abstract}

Changes in the environment that are caused by the activity of beavers bring numerous advantages. They affect the increase in biodiversity, contribute to improving the condition of cleanliness of watercourses, improve local water relations and restore the natural landscape of river valleys.

Rapid increase in the European beaver population in Poland in 21st century determines and accelerates the process of renaturalization of the areas that have undergone partial degradation as a result of anthropopressure. A singular example is the river valleys populated by beavers that have been adapted to people's needs in the last centuries, which has inevitably exerted an undesirable effect.

\section{(C) IOŚ-PIB}

\section{INTRODUCTION}

At the turn of the $19^{\text {th }}$ and $20^{\text {th }}$ centuries in Europe, the beaver population exceeded only 1000 specimens [Klich, Jarek 2013]. It was the consequence of practically definite extermination that had taken place since the Middle Ages [Janiszewski, Misiukiewicz 2012, Klich, Jarek 2013]. Since the end of $19^{\text {th }}$ century, many European countries have been taking actions aimed at increasing the population of these animals [Janiszewski, Misiukiewicz 2012]. In Poland, the critical period was 1970s, when as a result of reintroduction, a clear increase in the headage occurred [Czech 2010], which in 2000 exceeded 20,000 and in 2011 amounted to nearly 80,000 specimens [Dmochowska (ed.) 2012]. Therefore, the statistics reveal a dramatic increase that has occurred in Poland recently (Figure 1). Due to parallel restitution programs and favourable environment, a similar trend has been noticed in the countries of Northern, Central and Eastern Europe [Halley et al. 2012].
**** Dr hab. Bożena Wójtowicz, prof. nadzw. - Institute of Geography, Pedagogical University in Krakow, Podchorążych 2 St., 30-084 Warsaw ***** Dr inż. Elżbieta Wszelaczyńska - Department of Food Technology, Technology in Bydgoszcz, Kordeckiego 20A St., 85-225 Bydgoszcz Faculty of Agriculture and Biotechnology, UTP University of Science and

Streszczenie

Przekształcenia środowiska będące skutkiem działalności bobrów niosą dużo korzyści. Wpływają na zwiększenie bioróżnorodności, przyczyniają się do poprawy stanu czystości cieków, polepszają lokalne stosunki wodne oraz przywracają naturalny krajobraz dolin rzecznych.

Gwaltowny wzrost populacji bobra europejskiego na terenie Polski w XXI w. determinuje i przyśpiesza proces renaturalizacji obszarów, które w wyniku antropopresji uległy częściowej degradacji. Szczególnym przykładem są najczęściej zasiedlane przez bobry doliny rzeczne, które w ostatnich stuleciach zostały dostosowane do potrzeb ludzi, co nieuchronnie przyniosło niepożądany efekt.

These days, the European beaver is an ecologically flexible animal. Apart from areas not covered by human activity, it more and more often occupies biotopes transformed as a consequence of anthropopressure [Bereszyński, Homan 2007], which produces numerous positive effects, particularly in the case of resettling degraded river valleys.

The increase of beaver population in recent years in Poland is becoming a significant problem in the proper protection of agricultural areas and those endangered by floods. Negative effects of beavers' impact on the local environment are well known [Flis 2013], including the destruction of river banks and levees [Kołodziejczyk, Warcholak 2004]. It does not mean, however, that beavers with their natural behaviour do not produce positive effects on the environment [Derwich, Mróz 2008]. The article presents positive aspects of the beavers' impact on the environment in the renaturalization process of river valleys at times of growing anthropopressure. 


\section{INFLUENCE OF BEAVERS' ACTIVITY ON BIOTOPES OF RIVER VALLEYS}

Apart from the Canadian beaver, the European beaver is the only animal species living in the temperate climatic zone that can adjust the environment to its own needs [Stopka 2011]. Its existence affects the functioning of the whole ecosystem [Janiszewski, Misiukiewicz 2012]. The activity of the species is noticeable mostly within the areas of watercourses [Mróz 2010]. The beavers build structures there that change the local hydrological conditions [Czech 2010, Stopka 2011]. Consequently, they launch environment-forming processes that lead to renaturalization of the occupied area [Derwich, Mróz 2008].

The main aim of beavers' activity is slowing the flow and mounting water in watercourses, which leads to forming ponds and ensuring favourable living conditions. Water retained in these ponds soaks into the ground increasing the level of ground water [Czech 2010]. At the same time, several hectare backwaters are formed which irrigate the floodplains [Mróz 2010]. The improvement in local water relations determines the development of edaphic fauna and moisture-loving plants. Valley bottoms become covered by willow thickets, birch and willow bushes, water meadows, black alder bog woodlands, oak-hornbeam forests, while herbaceous vegetation spreads along river bed areas. The increasing biomass provides more and more food for numerous animal species. Physical and chemical changes in the mounted water contribute to the development of plankton which, in the new hydrological conditions, attracts invertebrates and the latter attract fish. Wetland meadows that have been formed in the areas of floodplains are becoming more and more attractive to roe deer, moose, wild boars and small mammals, whereas the areas of beaver ponds are populated by amphibians and reptiles. Extended ecotone, numerous islands, overturned trees, multitude of insects and water plants make ideal conditions for nesting, which many bird species benefit from (Fig. 2) [Czech 2010, Janiszewski, Misiukiewicz 2012]. Consequently, the processes launched by beavers' activity lead to a significant increase in the biodiversity in river valleys populated by these animals (Table 1). Dams and backwaters perform the function of a mechanical and biological purification plant of river waters. Pollution that reaches a beaver pond undergoes sedimentation and sorption. Next, in this type of slimy settler, the biochemical processes start. Microorganisms that populate it pick heavy metals. Acidified water becomes neutralized; after that, it is filtered and oxygenated while flowing through a dam [Czech 2005, 2010, Janiszewski, Misiukiewicz 2012].

Also, beavers directly shape the environment. They dig dens, canals and tunnels that visibly change the surface of an area within watercourse sides and affect the fluvial and slope processes [Kobojek 2013, Stopka 2011]. The activity enables irrigating additional areas chosen by the beavers [Stopka 2011] that frequently include oxbows and palaeochannels or simply corridors that are being dug.

Hydrological and morphological changes and increase in biodiversity result in transforming a landscape which becomes more diverse and closer to the natural one. The environment that is formed resembles the unharnessed and pollution-free land that existed thousands of years ago.

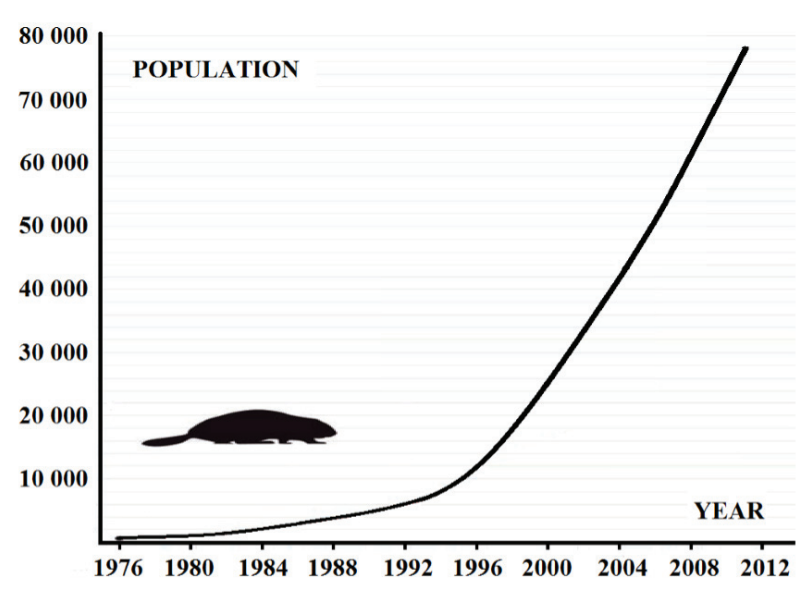

Figure 1. Changes in the population of the European beaver in Poland in 1976-2012 [developed on the basis Czech 2010, Dmochowska (ed.) 2012]

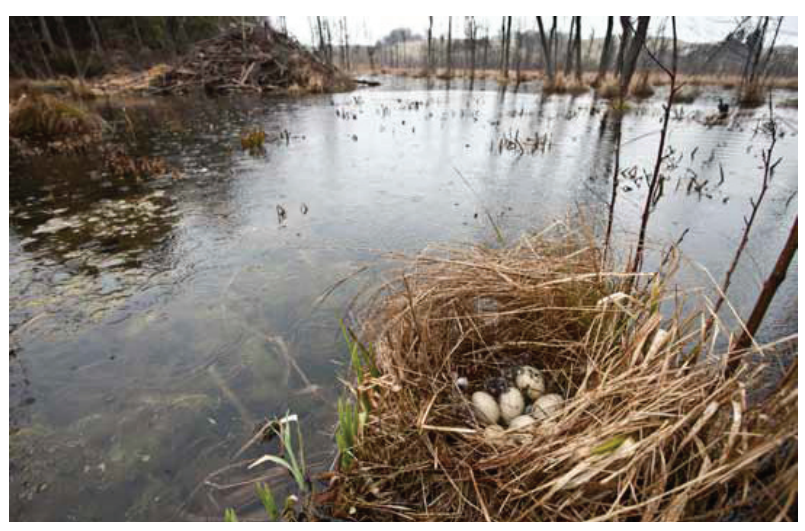

Figure 2. Nesting site of a wetland bird in a beaver backwater [Janiszewski, Misiukiewicz 2012, photo W. Misiukiewicz]

\section{THE SIGNIFICANCE OF THE EUROPEAN BEAVER ACTIVITY IN THE ERA OF INCREASING ANTHROPOPRESSURE}

Along with the development of civilisation, people successively transform the environment, step in new, so far undeveloped lands subordinating them to their own needs and causing enormous damage at the same time. Interference into the natural processes occurring in the environment is frequently followed by undesirable and even tragic results. A striking example is controlling hydrological phenomena in river valleys by people. Present needs resulting from the developing economy determine grabbing and transforming floodplains, straightening, deepening and developing river beds and a variety of other activities that degrade the environment. Time has revealed that these activities have not only eliminated natural animal habitats and disfigured the landscape, but have also turned against humans eventuating in catastrophic floods. Present hydrotechnical infrastructure of many rivers escalates the flow that once covered vast floodplains and now cumulates in narrow, concrete corridors; thus, mounting flood waves, so far unknown to humans that repeatedly cause havoc in housing estates built in the wrong locations. Another 
Table 1. Selected changes introduced by the European beaver in ecosystems of river valleys [Czech 2010, modified]

\begin{tabular}{|c|c|}
\hline Morphological and hydrological changes in a stream area & $\begin{array}{l}\text { 1. Slowing the flow. } \\
\text { 2. Flooding the area above a dam and stabilizing water level. } \\
\text { 3. Forming a waterside area typical of a pond. } \\
\text { 4. Increasing the open space around a formed pond. } \\
\text { 5. Interrupting stream continuity. } \\
\text { 6. Accumulating mineral and organic sediments in a pond. }\end{array}$ \\
\hline $\begin{array}{l}\text { Changes in physical and chemical qualities of water and } \\
\text { sediments }\end{array}$ & $\begin{array}{l}\text { 1. Modification in the circulation of elements. } \\
\text { 2. Increase in oxygen concentration. } \\
\text { 3. Increase in temperature. } \\
\text { 4. Acidity reduction. } \\
\text { 5. Increase in the number of carbon, nitrogen, phosphorus compounds } \\
\text { and other nutritional substances. }\end{array}$ \\
\hline Biological changes & $\begin{array}{l}\text { 1. Change in the proportion of plant and animal species. } \\
\text { 2. Increase in biodiversity of plant and animal species. } \\
\text { 3. Increase in biomass production. } \\
\text { 4. Increase in the activity of anaerobic microorganisms in sediments. } \\
\text { 5. Increase in the activity of aerobic microorganisms at the bottom of } \\
\text { a pond. }\end{array}$ \\
\hline
\end{tabular}

threat is polluting the rivers by channelling the municipal and industrial wastes into them. The effect was, among others, the famous 'Tomato Island' in the Vistula, where tomato plantations were formed as a consequence of tomato seeds being transported from sewers by the river [Samborska 2010]. Except for such caricatural consequences, the pollution poses various and more serious threats, among others to people's health. The condition of European watercourses is proved to a high degree by the state of one of the main receiver of their water - the Baltic Sea, which for several years has been predicted to transform into 'a dead sea' [Fabisiak 2008]. The consequences bear at least over-regional dimension. Not only are the consequences felt within a region but they reach further areas, as well. However, what must be remembered is that major tragedies occur in a local environment, where, for instance, a very small river provides water for a huge population (for example, Citarum in Indonesia) [Jarosz 2014], or where simply a major city is situated on a minor watercourse that is the only water supplier.

As a result of the far-reaching undesirable consequences, there have been introduced numerous programs aimed at restoring the former environment of the valleys that did not pose such a serious danger at the time when they existed naturally. A renaturalization program included, among others, the Rhone where, for example, the main river bed was connected with its oxbows so that better water retention facilities of the river basin could be restored [Parisot 2014]. Similar actions, but on a smaller scale, were taken in Polish river valleys [Żelazo 2006]. The ability to restore the primeval environment by beavers was noticed and applied successfully as a tool supporting renaturalization in the San river valley (Fig. 4, Tab. 2) [Derwich, Mróz 2008]. There were also recorded situations when animals, without human share, prevented a flood [Collier 1965] or just enriched the nature.

The significance of beavers' activity is presented in the findings of the research conducted by scientists from the Jagiellonian University in 2003 that reveal that at least several million cubic metres of water are retained in the backwaters of these animals in Poland. The amount can be compared to the effects of all national

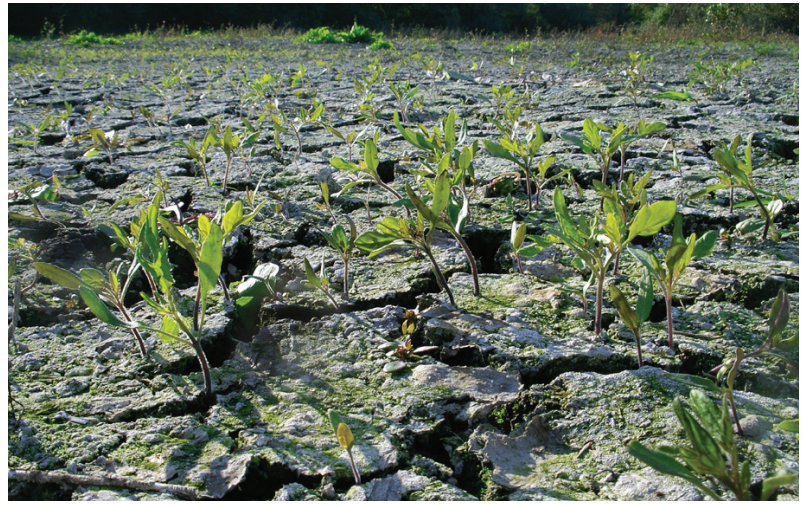

Figure 3. Tomato seedlings growing on sewage sediments covering 'Tomato Island' in the Vistula [Samborska 2010, photo M. Ostrowski].

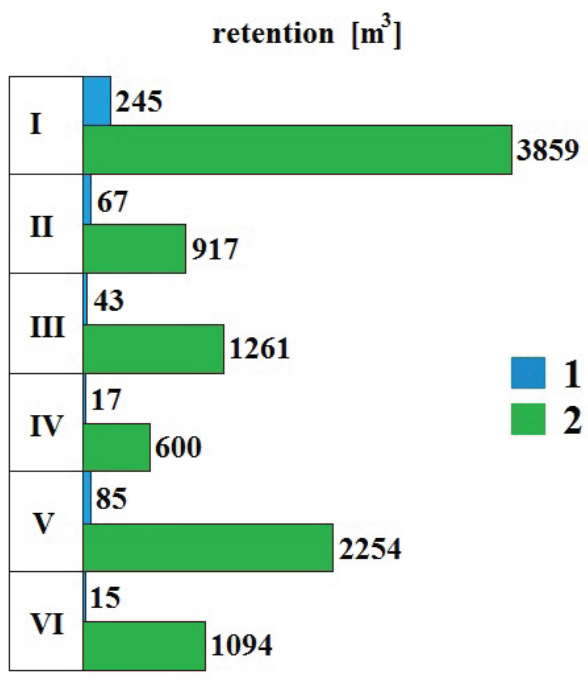

Figure 4. Changes in water retention recorded in 6 positions $(I-\mathrm{VI})$ in the valley of the Upper San river before the introduction of beavers (1) and after 5 years of their settlement (2) [Derwich, Mróz 2008]. 
Table 2. The number of plant species before the introduction of beavers and after 5 years of their settlement in 6 positions in the valley of the Upper San river [Derwich, Mróz 2008]

\begin{tabular}{|c|c|c|c|c|c|c|}
\hline Position & I & II & III & IV & V & VI \\
\hline $\begin{array}{c}\text { Number of taxa at the } \\
\text { time of the introduction }\end{array}$ & 29 & 39 & 26 & 26 & 31 & 23 \\
\hline $\begin{array}{c}\text { Number of taxa after } 5 \\
\text { years }\end{array}$ & 37 & 47 & 38 & 40 & 40 & 34 \\
\hline
\end{tabular}

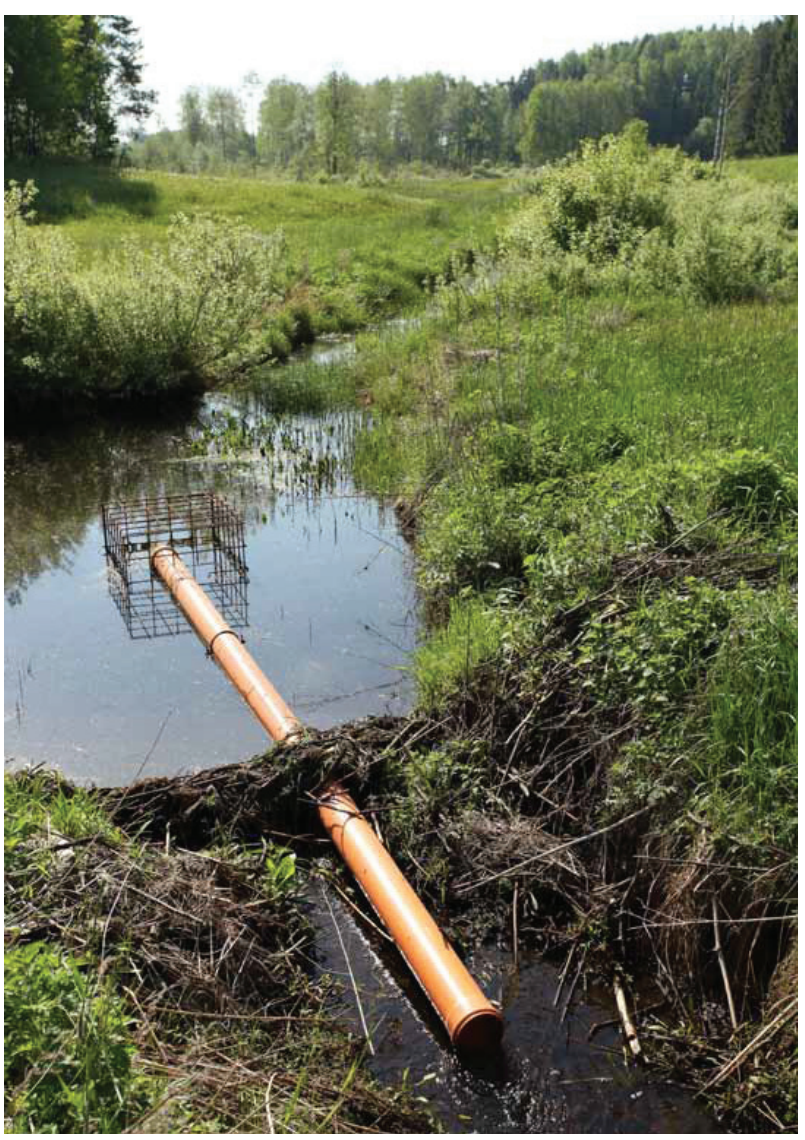

Figure 5. An overfall pipe regulating water level in a beaver pond, protecting against the undesirable irrigation of the area [Janiszewski, Misiukiewicz 2012, photo W. Misiukiewicz]

programs of small retention altogether [Czech 2010]. The results of beavers' activities undeniably influence the water economy of many basins and provide anti-flood protection. Clearly, the rapid increase in their population in recent years has contributed to it and has risen the scale of the influence of these creatures that, without doubt, was much smaller 20 years ago.

Along with the increase in the population of beavers, the problems connected with their harmful activities have increased [Wajdzik et al. 2013], which may encourage humans to eliminate the dangerous individuals. However, on the grounds of the benefits that they bring for the society, the methods of solutions should not determine the decrease in the population, but should lead to a

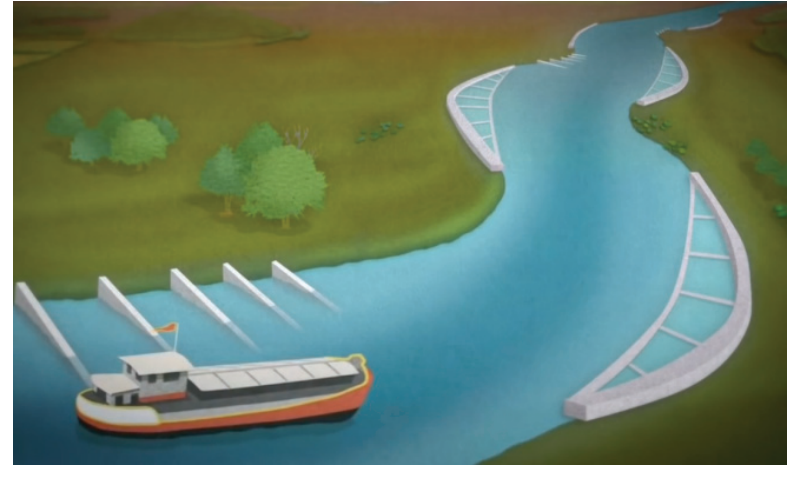

Figure 6. The pattern of hydro-technical development aimed at narrowing and deepening river bed, so that the sailing conditions on the Rhone can be provided [Parisot 2014]

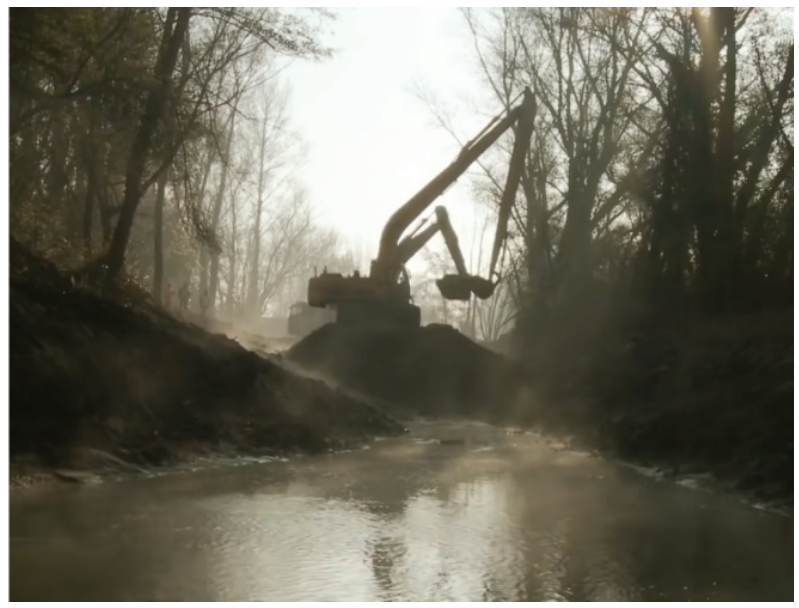

Figure 7. Renaturization works in the Rhone valley [Parisot 2014]

compromise gained by means of technical conceptions (Fig 5). Bearing in mind the potential and the examples of effective utilization of beavers, in the future, we should not forget about the possibility to benefit from their skills. There are many river valleys that need to be renaturized, where the introduction of these rodents would certainly bring results similar to those obtained in the area of the Upper San river (Fig. 4, Tab. 2). Thanks to their abilities to adapt, they can prove useful in the environment affected by industrial activities, in the suburban or even urban environment, where they could appear to be as useful for the surrounding as in the case of protected areas. The influence was noticed, among others, in Poznań [Bereszyński, Homan 2007]. A particularly pragmatic activity is introducing beavers in the area of fast-flowing mountain streams, where they minimalize the results of the surface erosion and amortize water surging [Derwich, Mróz 2008] that often threaten infrastructure and nearby towns.

\section{SUMMARY}

The blame of ecological and financial losses often lies with the development of rivers, so that it can satisfy the economic and energetic needs of the society (Fig. 6). These days, the rivers frequently 'suffocate'. Their flow is disturbed, landscapes denatured and biodiversity depleted [Bucała 2011, Parisot 2014]. 
That is why urgent actions are taken that aim at improving the present state of river valleys (Fig. 7) [Żelazo 2006, Parisot 2014]. Beavers appear to be the allies in these actions, since they perform an increasingly significant part in shaping the environment. Despite the harm that they cause, their activity contributes

\section{REFERENCES}

BERESZYŃSKI A., HOMAN E. 2007. Występowanie bobra europejskiego (Castor fiber L.) w Poznaniu. Nauka, Przyroda, Technologie. 1, 2: 1-43.

BUCAŁA A. 2011. Wpływ regulacji technicznej na zmiany morfologii górskiego potoku: potok Jamne, Gorce. Acta Sci. Pol., Formatio Circumiectus. 10, 1: 3-15.

COLLIER E. 1965. Nad rzeką bobrów. Naokoło Świata, Państwowe Wydawnictwo, Iskry". Warszawa.

CZECH A. 2005. Analiza dotychczasowych rodzajów i rozmiaru szkód wyrządzanych przez bobry (Castor fiber) oraz stosowanie metod rozwiązywania sytuacji konfliktowych. Instytut Ochrony Przyrody PAN. Kraków.

CZECH A. 2010. Bóbr - budowniczy i inżynier. Fundacja Wspierania Inicjatyw Ekologicznych. Kraków.

DERWICH A., MRÓZ I. 2008. Bóbr europejski Castor fiber L. jako czynnik wspomagający renaturyzację siedlisk nad Górnym Sanem. Studia i Materiały Centrum Edukacji PrzyrodniczoLeśnej. 10, 2 (18): 173-183.

DMOCHOWSKA HALINA (ed.) 2012. Mały Rocznik Statystyczny Polski. GUS. Warszawa.

FABISIAK J. 2008. Zagrożenia ekologiczne Bałtyku związane z zanieczyszczeniami chemicznymi - węglowodory. Zeszyty Naukowe Akademii Marynarki Wojennej. XLIX, 3 (174): 7-28.

FLIS M. 2013. Aspekty oceny szkód wyrządzanych przez dzikie zwierzęta. Ochrona Środowiska i Zasobów Nauralnych. Vol $24 \mathrm{nr} 3(57): 53-58$.

HALLEY D., ROSELL F., SAVELJEV A. 2012. Population and Distribution of Eurasian Beaver (Castor fiber). Baltic Forestry. 18, 1 (34): 168-175.

JANISZEWSKI P., MISIUKIEWICZ W. 2012. Bóbr europejski Castor fiber. BTL Works. Warszawa.

JAROSZ W. 2014. Najbardziej zanieczyszczone miejsca świata. Zielona Liga. 1: 27-28. substantially to protecting and exceeding environmental supplies particularly within the habitats of river valleys. Consequently, the animals can be purposefully used to restore areas degraded due to anthropopressure.

KLICH M., JAREK S. 2013. Dolina Sanu jako środowisko występowania bobra europejskiego (Castor fiber) - bóbr i człowiek - nie zawsze łatwe współistnienie. w: KRUPA J. (red.), Ochrona środowiska, krajobraz przyrodniczy i kulturowy Pogórza Dynowskiego a rozwój turystyki. ZGTPD. Dynów. 175-186.

KOBOJEK E. 2013. Wpływ działalności bobrów na lokalne procesy fluwialne w wybranych rzekach Równiny ŁowickoBłońskiej. Acta Universitatis Lodziensis, Folia Geographica Physica, 12: 17-32.

KOŁODZIEJCZYK U., WARCHOLAK P. 2004. Bobry a bezpieczeństwo przeciwpowodziowe w województwie lubuskim, Gospodarka Wodna, 4:149-153.

MRÓZ I. 2010. Zmiany składu gatunkowego flory w strefie przybrzeżnej cieków wodnych Bieszczadzkiego Parku Narodowego jako efekt działalności bobra europejskiego Castor fiber L. Roczniki Bieszczadzkie. 18: 91-111.

PARISOT C-J. 2014. Le Rhone, La Renaissance D'un Fleuve. Francja. (film, dokument, $52 \mathrm{~min}$ ).

SAMBORSKA Z. 2010. Wyspa Pomidorowa w Warszawie. Warszawski Tryptyk Edukacyjny. Tom 2 - Skrypty: 179-184.

STOPKA R.. 2011. Geomorfologiczne skutki działalności bobra europejskiego Castor fiber w dolinie górnego Sanu. Roczniki Bieszczadzkie. 19: 319-334.

WAJDZIK M., KUBACKI T., TOMEK A. 2013. Szkody wyrządzone przez bobra europejskiego Castor fiber w gospodarce rolnej, leśnej i rybackiej w Małopolsce. Studia i Materiały CEPL w Rogowie. 15, 36/3: 131-137.

ŻELAZO J. 2006. Renaturyzacja rzek i dolin. Infrastruktura i Ekologia Terenów Wiejskich. 4, 1: 11-31. 